\title{
VALIDATING A PROJECT LIFE-CYCLE REVIEW FRAMEWORK FOR MINING PROJECTS AT EXXARO
}

\author{
J.R. Steenkamp ${ }^{1 \#} \&$ M.C. Bekker ${ }^{1 *}$
}

\section{ARTICLE INFO}

Article details

Submitted by authors 5 Jan 2017

Accepted for publication 6 Apr 2018

Available online $\quad 31$ May 2018

\section{Contact details}

Corresponding author

michiel.bekker@up.ac.za

\section{Author affiliations}

1 Graduate School of Technology Management, University of

Pretoria, South Africa

\# The author was enrolled for an MPM degree in the Graduate School of Technology Management, University of Pretoria, South Africa

\section{DOI}

http://dx.doi.org/10.7166/29-1-1711
Independent formal reviews against validated project frameworks aim to ensure that pre-specified phase deliverables are completed and validated before the next project phase begins. Through various internal initiatives, Exxaro established a project framework to develop and implement capital projects. However, to date, this framework has not been validated. The intent of this research was, through a case study approach, to validate the project framework for Exxaro (a holistic case). Semi-structured interviews were conducted with sixteen key role players across the organisation on four different projects (embedded cases). Results from the embedded cases were compared to identify common themes emerging from the research. Although the research identified areas for improvement for certain aspects of the framework, the common themes correspond with the main aspects of the proposed framework, thus validating the framework.

\section{OPSOMMING}

Onafhanklike formele hersienings gemeet teen 'n gevalideerde raamwerk verseker dat uitkomste bereik word volgens vooraf gedefinieerde doelwitte, voordat die volgende projekfase mag begin. Deur verskeie interne inisiatiewe is 'n projekraamwerk ontwikkel vir die ontwikkeling en implementering van kapitaal projekte in die Exxaro omgewing. Maar, hierdie projekraamwerk was tevore nog nie gevalideer nie. Hierdie navorsing het gestreef om deur 'n gevallestudie benadering die projekraamwerk te valideer vir Exxaro projekte ('n holistiese geval). Semigestruktureerde onderhoude is met sestien sleutelrolspelers van regoor die organisasie gevoer oor vier verskillende projekte (ingeslote gevalle). Onderhoudresultate van die ingeslote gevalle studies is vergelyk om gemeenskaplike temas te identifiseer waarvolgens die raamwerk verbeter kan word. Die gemeenskaplike temas stem ooreen met die hoof aspekte van die voorgestelde raamwerk, en daarom kan die raamwerk as gevalideer beskou word.

Rudenno [1] states that the aim of a mining company is to find, develop, extract, and sell mineral resources at a profit in a responsible manner. To enable a mining company to extract the minerals, various capital projects need to be initiated to establish the capability and value chain to mine the deposit over the life-of-mine period.

Pearce and Robinson [2] describe the value chain as a perspective in which business is seen as a chain of activities that transform inputs into outputs that customers value. In Figure 1, a generic value chain for a mining project is depicted by adapting the Pearce value chain model. 


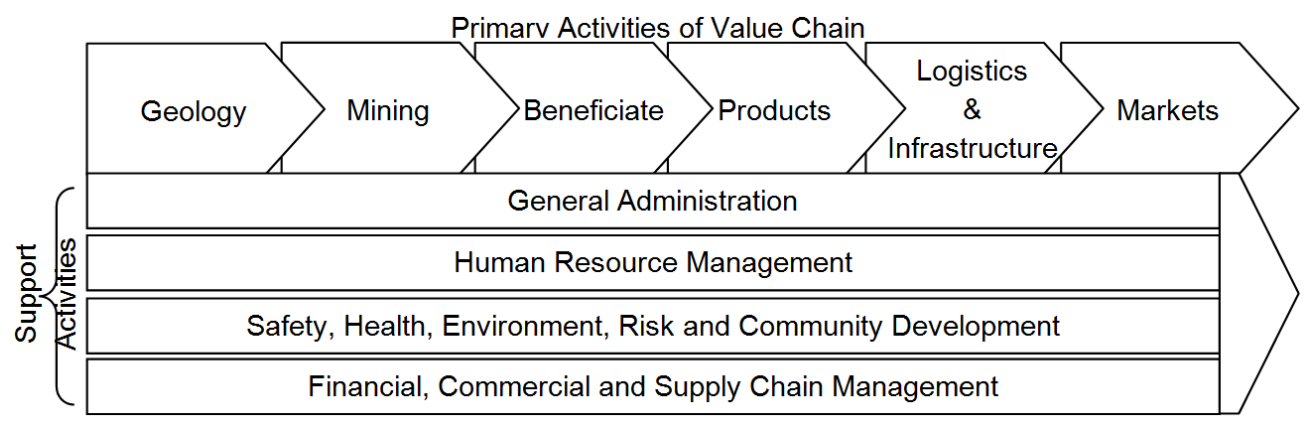

Figure 1: Value chain for a mining project [2]

When embarking on a new mine development, all the primary activities of the mine value chain and the supporting activities need to be addressed. Progressing from geology to mining involves the development and implementation of major capital projects. As with the total value chain, a project can be broken down into different phases, also referred to as a 'stage-gate' process.

Griffith and Yarossi [3] explain that the project life-cycle is a series of sequential phases through which a project passes from its initiation to its closure. The names and number of the phases are related to the control needs of the organisational management, the nature of the project itself, and its area of application. The phases can be broken down into functional objectives, intermediate results, specific milestones, and financial approval points. The project life-cycle can also be shaped by the dominant technology employed, or by the industry in which the project operates. A welldefined project life-cycle therefore provides the basic framework for managing the project, regardless of the specific work involved.

Exxaro has developed a stage-gate process framework to assist with the management of capital projects to support the mine value chain of the company. The process depicts a typical project lifecycle in the mining industry, and is referred to as the 'Exxaro project life-cycle process' (EPLP). The EPLP has been applied to various projects, but so far no form of validation of the effectiveness or applicability of the framework has been carried out.

This paper provides a brief overview of a stage-gate process, the content of the EPLP, and an attempt to validate the EPLP.

\section{PROBLEM STATEMENT}

The project framework developed and implemented by Exxaro has not been empirically validated against the stage-gate criteria and eventual performance-implemented projects.

\section{RESEARCH QUESTIONS}

The primary research question to be addressed is whether the application of the Exxaro project framework had an impact on the performance of implemented projects. Sub-sequent questions are: (i) To what extent have project reviews been applied to projects in Exxaro? and (ii) What could be done to improve the framework?

\section{LITERATURE REVIEW}

Griffith and Yarossi [3] explain that a stage-gate process involves breaking the project life-cycle down into separate phases, with specific objectives and deliverables for each phase. Projects are reviewed at the end of each phase by comparing them with the predefined phase objectives and deliverables. With satisfactory adherence to the objectives and deliverables, the project may 'pass' through the 'gate' to the next phase. The stage-gate approach is controlled via 'go' and 'no-go' decision-criteria, and helps to shape and select the best investment opportunities [3]. The stagegate process is well established in the project management fraternity [4]. Exxon Research and Engineering developed a work process as early as the 1960s that is similar to the project life-cycle 
processes that are now fairly standard practice in the oil, chemical, pharmaceutical, and minerals industries [4].

Focusing more on the criteria for gate decisions, Liu and Yetton [5] highlighted the importance of proper gate reviews in terms of project progress, budget and cost variance, business objectives, and resolving problems in executing a project. They also tested the hypothesis that 'conducting project reviews improves project performance' by evaluating 232 Australian construction companies. Their results indicate that construction organisations improve their project performance by conducting project reviews to provide performance feedback to the project teams, enabling them to make timely adjustments to their projects [5]. Because the engineering and project management departments are usually the custodians of the stage-gate process, it is often assumed that it should meet a technical or engineering purpose. However, the gates serve more as a business purpose, allowing 'hold' points in the development process so that decisions to stop, recycle, or proceed with the project [4] can be made.

During the process to establish a review framework for projects in Exxaro, the policies and procedures of the companies that led to the formation of Exxaro were studied in an attempt to amalgamate them into one framework that would suit the needs of the company [6]. Although some are comprehensive, these documents are company policies, developed by individuals or groups with limited reference to the literature or the theory on project reviews. This complicated the validation of empirical parameters and the theoretical basis of the final framework. Nevertheless, the actual application and effectiveness of the framework content against the actual business results remains the ultimate test; and thus far that has not been done.

The Construction Industry Institute (CII) [7] refers to the earlier phases of the project life-cycle as 'front-end planning' (FEP). CII developed a project review metrics tool to determine the readiness of a project to progress to the next phase in the project life-cycle. In a survey of 96 construction projects, it showed that the companies that have a high use of reviews on average reduced costs by 3.3 per cent, whereas companies with a low use of review processes had an average cost growth of 5.4 per cent [7].

Noakes and Lanz [13] regard studies during the earlier phase of projects as part of the project development spectrum. Detailed studies and subsequent reviews occur at the early stage of the project life-cycle, during which the greatest influence in shaping the project can be exerted before designs are frozen and a much greater financial commitment is made to move into implementation.

Evidently, the proper review and assurance of a project across its life-cycle remains a governance function. The Exxaro business model seeks to confirm the alignment of the company's strategic corporate governance model with the governance exerted at the project level. This alignment should be validated and confirmed as part of the total corporate governance imperatives [3], [6], [8], [9], [10], [11], [12], [14].

\section{EXXARO PROJECT LIFE-CYCLE PROCESS}

The Exxaro project assurance and gate review procedure [6] describes the comprehensive EPLP, as shown in Figure 2. The assurance activities of this EPLP entail more than just the structure of the review framework. For the purpose of this research, the focus is only on the review activities of the EPLP. 


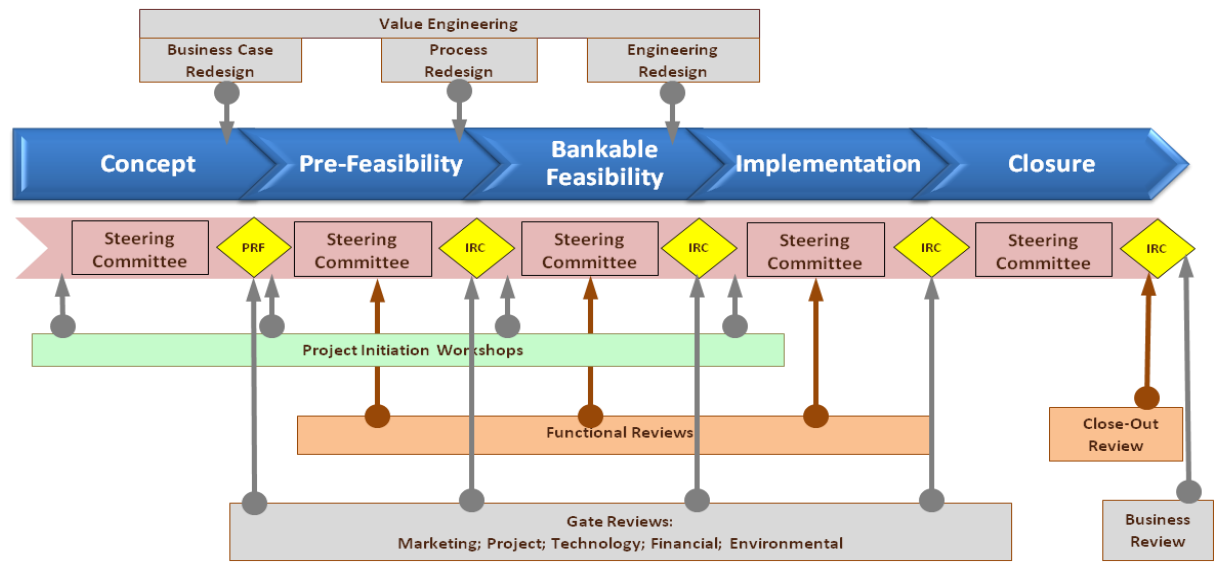

Figure 2: The Exxaro project life-cycle process (EPLP) and stage-gate reviews

The purpose and focus of each phase is well-documented, and is briefly explained below. (Note that Exxaro adopted the independent project analysis (IPA) terminology [4] of front-end-loading (FEL) instead of front-end planning (FEP) or front-end engineering design (FEED), as it is also often referred to.)

- $\quad$ Gate 1 (FEL 1): Concept - confirms a sound business case [6].

- $\quad$ Gate 2 (FEL 2): Pre-feasibility - ensures that options are generated and a viable single 'goforward' option has been identified [6].

- $\quad$ Gate 3 (FEL 3): Bankable feasibility - ensures that the complete scope of work and project execution plan for the execution phase is compiled before approval [6].

- $\quad$ Project implementation - comprises the design and execution of the project [6].

- $\quad$ Project closure - ensures that the project is completed as required and the client takes over the project operating as a fully functional unit [6].

The focus of each phase determines the gate-decision criteria. The project governing body (also referred to as the project steering committee), sponsor, or senior management needs to review the results of the phase and provide guidance on project continuation or termination.

\subsection{Project reviews}

In line with Oakes [9], project reviews should not be done in an ad hoc way, but should rather be well-planned and well-structured. Each review should be viewed as a system, with inputs, outputs, and controls (see Figure 3).
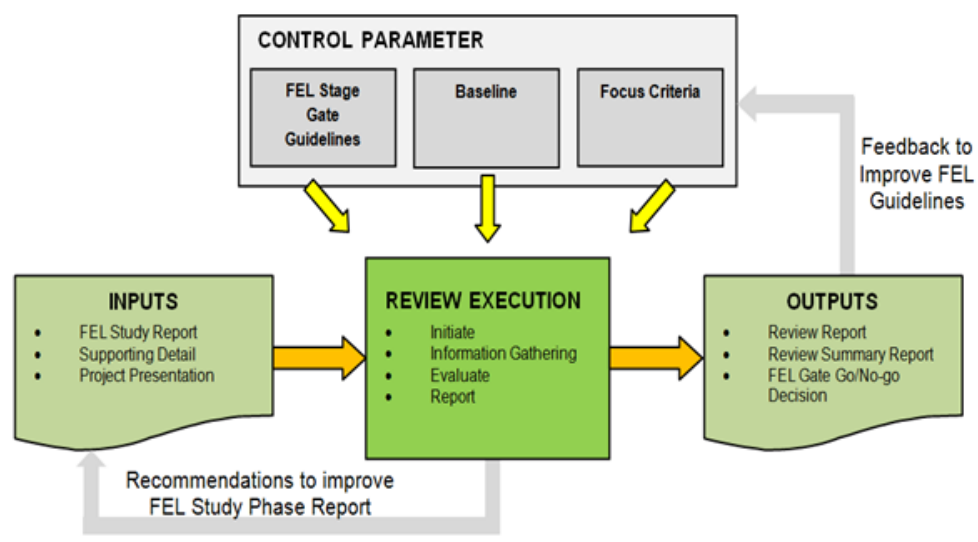

Figure 3: Process model for a review for Exxaro (after Oakes [9]) 
Focusing on the 'review execution', the follow activities should be addressed during this process:

- Initiate: Once the FEL study phase report has been completed and signed off, a review is initiated. A review team is assembled and the background is explained [6].

- Information-gathering: All the project information is shared in a work session. The review team then continues to gather further information [6].

- Evaluation: The actual review happens in separate sessions and discussions. All the high risks are identified and evaluated [6].

- $\quad$ Report: All the members' reports are collated into a summary report. This is formally submitted to the Internal Review Committee (IRC) to make the final gate decision [6].

Each review requires the following control parameters to guide the process:

- $\quad$ Stage-gate guidelines and standards: To prevent reviews degenerating into debates about methodologies and standards, it is essential that there is an official reference document that clearly defines the requirements.

- $\quad$ Baseline: Defines what has been agreed prior to the review and what is relevant to the specific project [9].

- $\quad$ Focus criteria: Guide the review over a time line. Reviews extend over the life-cycle of the project and the approved time frame. This can be shortened, if planned well [9].

The Exxaro project life-cycle guidelines [14] were compiled from best practices documented by companies such Anglo American, Kumba Resources, and Eskom. Hatch Consulting also gave input to the Exxaro FEL guidelines. From the literature survey, it became apparent that these company documents draw from the CII project definition readiness index tool (PDRI) [7] for projects in general, and from the IPA [4] FEL process for resource projects in particular. Mining-specific texts on project definition, such as The mining valuation handbook [1] and the latest edition of the Cost estimation handbook [13] were also applied. The FEL guidelines aim to integrate all the elements of the mining value chain to the project review framework.

In line with the FEL guidelines, the review should feed information back to the project for validation. This is done in order to:

- $\quad$ ensure that all project findings are captured in the final close-out report [9]; and

- $\quad$ provide feedback to the FEL guidelines, thus helping to build organisational learning by updating the guidelines described as control parameters [9].

\subsection{Gate review team}

As stated in the Exxaro framework [7], the composition of the project review team needs to be representative of various disciplines and functions, as listed below:

- A facilitator provided by the project assurance function.

- $\quad$ Technical managers for each functional area who will sign off the report.

- Additional technical experts for disciplinary fields, such as mechanical, civil, electrical, metallurgical, etc.

- $\quad$ Cost estimating, scheduling, and risk expertise, relevant to the project scope.

- $\quad$ Experienced project managers who have managed similar projects.

- $\quad$ Finance, marketing, and environmental affairs on an ad hoc basis, as required.

Gate reviews should have one of three outcomes: approve, hold, or fail [3]. 'Approve' means that the project may continue to the next stage, and funding should be made available. 'Hold' means that the project should recycle the phase for additional definition; and 'fail' obviously means that the project should be shelved or cancelled.

\subsection{Review framework for EPLP}

Kululanga and Kuotcha [15] explored the development of a structured tool to measure the constructs of the project review process. In their research, they found that some of the vital lessons that could 
have been learned from project reviews are lost by organisations due to the lack of a structured framework for undertaking them.

Apart from validating the project review framework, it was also necessary to confirm that it is grounded in theory. This was confirmed by reviewing the Exxaro internal procedures and guidelines [6], [14]. The basic elements of the framework formed the basis on which to review capital projects in the mining industry (Table 1 ).

Table 1: Basic elements of a generic project review framework

\begin{tabular}{|c|c|}
\hline \multicolumn{2}{|c|}{ - $\quad$ The gate review mechanism } \\
\hline & Purpose of review \\
\hline & Timing of the gate review \\
\hline \multicolumn{2}{|r|}{ Project governance } \\
\hline & $\circ \quad$ Independence of reviews \\
\hline & Roles and responsibilities \\
\hline$\bullet$ & Project life-cycle process (PLP) \\
\hline$\bullet$ & Gate descriptions \\
\hline$\bullet$ & The gate review process \\
\hline & Inputs \\
\hline & Outputs \\
\hline & Review execution \\
\hline & Control parameters \\
\hline$\bullet$ & Gate review team \\
\hline$\bullet$ & Gate review outcome \\
\hline$\bullet$ & Industry specific guidelines for FEL studies \\
\hline & Key deliverables \\
\hline
\end{tabular}

It should be noted that the participants in the study by Kululanga and Kuotcha [15] voiced their concern about the lack of established criteria and guidelines to conduct project reviews. This emphasised the need for an improved framework.

\section{RESEARCH DESIGN AND METHODOLOGY}

\subsection{Research design}

The elements listed in Table 1 formed the basis of the research design. It was believed that these elements, structured in the given framework, would prompt discussion among project sponsors, project managers, project governance officials, technology managers, and other company experts within Exxaro towards validating the project review framework. Since the target audience is specific to those directly involved in projects, a focus group approach was adopted.

Yin [16] describes the case study as a good method to work with situations that uncover a phenomenon by testing a theory, model, or framework and creating causal links. The case study method is chosen when the research design operates under the following conditions [16]:

- The type of research question is classified as a 'how' type of question.

- $\quad$ There is no need for behavioural control.

- There is a need to focus on contemporary events.

The four dimensions of case study research design described by Mouton [17] and Yin [16] are tests of construct validity, internal validity, external validity, and reliability. Yin [16] developed a $2 \times 2$ matrix that resulted in four types of designs for case studies: (Type 1) single-case (holistic) designs, (Type 2) single-case (embedded) designs, (Type 3) multiple-case (holistic) designs, and (Type 4) multiple-case (embedded) designs. For this case study, Type 2 was considered the most suitable, and was deconstructed as follows:

- $\quad$ The context is the mining industry. The projects that will be evaluated are all mining projects, and the aim will be to generalise the review framework to the mining industry in which Exxaro operates. 
- The single case is Exxaro, as all the projects will be Exxaro projects, reviewed according to the Exxaro framework. The rationale used, as described by Yin [16], is a representative or typical example, with Exxaro believed to be typical of many other mining firms in the same industry.

- The embedded units of analysis are the four projects that will be analysed to validate the framework. These projects are:

- Case 1 - Mayoko: a greenfields iron ore project located in West Africa. Through a beneficiated high-value product, markets in Europe will be targeted [18].

- Case 2 - Belfast: potentially the last sizeable coal project that Exxaro has in Mpumalanga, strategically placed for both exports and Eskom supply [19].

- Case 3 - Thabametsi: a mega-scale coal resource in the Waterberg (Limpopo) that will supply coal to an independent power producer [20].

- Case 4 - Leeuwpan Ol: located near Delmas in Mpumalanga, this involves a major brownfields expansion of the current Leeuwpan Mine [21].

\subsection{Research methodology}

To answer the research question on how a review framework for mining projects can be validated, a holistic case study research with embedded cases was employed. Sixteen individuals were interviewed from across the organisation. This entailed a study of the four major projects (covering the complete value chain) currently undertaken by Exxaro (holistic case). For each of the four projects (embedded units of analysis), interviewees were drawn from one of four categories associated with each project:

- $\quad$ Project manager of the project.

- $\quad$ Project governance, which included members of the project steering committees.

- Client or sponsor of the project.

- Technology or engineering manager involved in the review of the project.

During the case study, the four basic tests prescribed by Yin [16] - construct validity, internal validity, external validity, and reliability - were applied. To satisfy these tests, a case study protocol was created to ensure a consistent, coordinated, and standardised approach by which data were obtained and captured in the case study database [16]. This established and maintained a chain of evidence [16] during the case, which links the research question via the protocol and database with the research results.

The interviews were conducted in a semi-structured manner. The importance of distinguishing the interview from a survey was highlighted to each interviewee and, due to the expertise of the individuals and their knowledge of the projects, value-adding discussions followed on each topic of the review framework.

The data from the interviews were analysed and presented so that conclusions about the validity of the project review framework could be made. Although the results indicated that some areas were not well applied on the projects (embedded cases) or in Exxaro (the holistic case), the data still revealed that it was deemed important and, if applied correctly, would benefit projects.

\subsection{Data collection procedures}

Each interview was structured around an interview protocol [16] that was developed to extract the information about the review framework in a more quantitative manner to simplify the analysis. Sixty statements were made in the questionnaire. The interviewee then needed to score each statement ( $1=$ low to $5=$ high), measured against the following questions:

Q1: To what extent is this statement applied at Exxaro?

Q2: How important is this statement to the interviewee to ensure a proper review?

Q3: To what extent was this statement applied or implemented for the specific project?

Q4: If the statement was applied correctly, how would it impact the project?

Q5: Could the specific action be done better on the project and be improved at Exxaro?

The questionnaire also aimed to validate the FEL guidelines. The interviewee had to:

- $\quad$ Review the FEL guidelines, and note whether any critical lines should be added (or removed), and whether the requirement for each phase of the EPLP is correct. 
- $\quad$ Score the project with regard to overall compliance for each sub-heading.

The case study database was retrieved and, for each interview, a detailed record was kept. Each interview was audio-recorded and added to the database. All the raw individual data from each questionnaire were also secured in the database before any analysis was conducted.

\subsection{Data analysis}

Yin [16] explains that case study analysis cannot rely primarily on the use of statistics, and therefore calls attention to other ways of thinking about criteria by which findings are interpreted. In other words, care should be taken not merely to consider the averages of all the scores. As befits the nature of this study, it is important to consider the comments from each interviewee, together with the scores for each statement, to identify themes that emerge from the research.

With Likert data it is critical to differentiate between ordinal and interval data, as the two types require different analytical approaches. Adding a response of 'strongly agree' (5) to two responses of 'disagree' (2) would give a mean of 3; but what is the significance of that number? With Likert scale data, the best measure to use is the mode, or the most frequent response. Therefore, the most frequent responses of the retrieved data, from the interviews for all the main headings of the review framework, are presented in this way In Table 2.

The score for each of the five questions per statement can be referred to as the 'data groupings' for each statement. The data grouping for each statement shows certain distinct combinations. For example, if a statement shows a grouping of $Q 1=5, Q 2=5, Q 3=5, Q 4=5$, and $Q 5=3$ (or 5, 5, 5, 5, 3), it will mean that, for this statement, it was well applied both at Exxaro (Q1) and on the project (Q3), the interviewee feels it is highly important (Q2), it had a positive impact on the project (Q4), and the correct level of attention was given to this activity (Q5). This equates to the interviewee being very satisfied with this statement, and that it is valid to include this activity in the review framework.

- A grouping leaning towards $(5,1,5,1,1)$ for a statement would certainly mean that this statement has been considered by a significant number of subjects to be undesirable. Table 2 shows that no statements lean toward this grouping, and the possible exceptions clearly emerged from the interviews.

- A grouping nearing $(x, 5, x, 5, x)$ (where $x$ is any score) shows that a significant number of interviewees considered the statement to be important, and that it will improve the project. Table 2 shows nearly all statements reflecting this grouping, and the exceptions also clearly emerged from the interviews.

- The mode for most headings is $(4,5,4,5,4)$. This means that, for most areas of the framework, a significant number of interviewees feel that the statements were very important $(Q 2=5)$ and that the application of the statements in the frameworkwould significantly improve the project if applied correctly $(\mathrm{Q} 4=5)$. However, it was mostly felt that framework is not always applied consistently at Exxaro (Q1 $\leq 4$, the holistic case), nor on each of the embedded cases $(\mathrm{Q} 3 \leq 4)$. It thus leaves room for at least some improvement in most areas ( $Q 5 \geq 4)$. 
Table 2: Modes for the main headings of the framework for all cases

\begin{tabular}{|c|c|c|c|c|c|}
\hline Review framework for mining projects & Q1 & Q2 & Q3 & Q4 & Q5 \\
\hline 1. Project life-cycle process (PLP) & 4 & 5 & 5 & 5 & 4 \\
\hline 2. Purposes of phases and descriptions & 4 & 5 & 5 & 5 & 4 \\
\hline 2.1 FEL-1: Concept study & 4 & 5 & 4 & 5 & 4 \\
\hline 2.2 FEL-2: Pre-feasibility study & 4 & 5 & 5 & 5 & 4 \\
\hline 2.3 FEL-3: Bankable feasibility study & 4 & 5 & 4 & 5 & 3 \\
\hline 3. Purpose of review & 4 & 5 & 5 & 5 & 4 \\
\hline 4. Reviews and governance & 5 & 5 & 5 & 5 & 4 \\
\hline 4.1. Independence of reviews & 5 & 5 & 5 & 5 & 3 \\
\hline 4.2 Roles and responsibilities & 4 & 5 & 5 & 5 & 4 \\
\hline 4.2.1 Organisational management & 5 & 5 & 5 & 5 & 3 \\
\hline 4.2.2 Project steercom & 4 & 5 & 5 & 5 & 4 \\
\hline 4.2.3 Project assurance & 4 & 5 & 5 & 5 & 4 \\
\hline 4.2.4 Corporate group managers & 4 & 5 & 4 & 5 & 4 \\
\hline 4.2.5 Functional group managers & 4 & 5 & 4 & 4 & 3 \\
\hline 5. Gate review process & 4 & 5 & 5 & 4 & 3 \\
\hline 5.1 Inputs & 5 & 5 & 5 & 5 & 4 \\
\hline 5.2 Outputs & 5 & 5 & 5 & 5 & 3 \\
\hline 5.3 Review execution & 4 & 5 & 5 & 5 & 3 \\
\hline 5.4 Control parameters & 3 & 5 & 4 & 4 & 4 \\
\hline 5.4.1 Baseline & 4 & 4 & 4 & 4 & 4 \\
\hline 5.4.2 Focus criteria: & 3 & 5 & 4 & 4 & 4 \\
\hline 5.4.3 Feedback to FEL guidelines & 3 & 5 & 4 & 4 & 4 \\
\hline 6. Gate review team & 4 & 5 & 4 & 4 & 3 \\
\hline 7. Gate review outcome & 5 & 5 & 5 & 5 & 3 \\
\hline
\end{tabular}

Table 3 shows how the interviewees rated the compliance of the different cases with the FEL study guidelines. For these responses, a high score (5) means a high level of compliance, and a low score (1) means a low level of compliance with the FEL guidelines, resulting in interval data. Therefore, in this instance, the average of the scores is more relevant, as it gives a better overall sense of the level of compliance. The results show that:

- $\quad$ Project managers tend to score their projects the highest.

- The group managers are most involved in the details of the FEL guidelines. They score the projects the lowest.

- Taking this bias into account, it can be seen that environmental approvals are regarded as the area of greatest concern.

- $\quad$ Exxaro's core areas of geology, mining and, to a lesser extent, processing, all obtained high scores. This reflects the general comfort that most interviewees had with these sub-areas of the FEL guidelines during the interviews.

- The area of scope definition was also highlighted as an area of concern.

- $\quad$ An additional theme that emerged from the interviews is that of integration management. This was raised by several interviewees from all areas. As this is not an area in the theoretical framework, no numerical data reflect this development. 
Table 3: Overall compliance with FEL study guidelines

\begin{tabular}{|c|c|c|c|c|c|c|c|c|c|}
\hline FEL study guidelines & A & C1 & $\mathrm{C} 2$ & C3 & C4 & A1 & A2 & A3 & A4 \\
\hline Overall average compliance & 3.8 & 3.8 & 4.2 & 4.0 & 3.4 & 4.2 & 4.0 & 3.8 & 3.5 \\
\hline Project scope definition & 3.6 & 3.3 & 4.3 & 4.0 & 3.0 & 4.0 & 4.0 & 3.5 & 3.0 \\
\hline Site information & 4.3 & 4.5 & 4.5 & 4.0 & 4.3 & 4.5 & 4.3 & 4.5 & 4.0 \\
\hline Geology & 4.3 & 4.5 & 4.8 & 4.0 & 4.0 & 4.8 & 4.3 & 4.0 & 4.3 \\
\hline Mining & 4.0 & 4.0 & 4.3 & 4.0 & 3.5 & 4.3 & 4.3 & 3.8 & 3.5 \\
\hline Processing & 3.7 & 3.5 & 4.0 & 4.0 & 3.3 & 4.3 & 4.0 & 3.5 & 3.0 \\
\hline Infrastructure & 3.8 & 3.3 & 4.5 & 4.5 & 3.0 & 4.3 & 3.8 & 3.8 & 3.5 \\
\hline Engineering design & 3.8 & 3.8 & 4.0 & 4.0 & 3.5 & 4.3 & 3.8 & 3.8 & 3.5 \\
\hline Environmental approvals & 3.5 & 3.5 & 3.8 & 3.8 & 3.0 & 3.5 & 4.0 & 3.8 & 2.8 \\
\hline Project implementation & 3.8 & 4.0 & 3.8 & 4.0 & 3.3 & 4.3 & 3.5 & 3.8 & 3.5 \\
\hline Financial evaluation & 3.8 & 3.3 & 4.3 & 4.3 & 3.5 & 4.3 & 4.3 & 3.3 & 3.5 \\
\hline Project risk analysis & 3.7 & 3.8 & 4.0 & 3.8 & 3.3 & 4.0 & 3.5 & 3.8 & 3.5 \\
\hline \multicolumn{5}{|l|}{$\begin{array}{l}\mathrm{A}=\text { Overall average } \\
\mathrm{C} 1=\text { Case } 1: \text { Mayoko } \\
\mathrm{C} 2=\text { Case } 2: \text { Belfast } \\
\mathrm{C} 3=\text { Case } 3: \text { Thabametsi } \\
\mathrm{C} 4 \text { = Case } 4: \text { Leeuwpan OI }\end{array}$} & \multicolumn{5}{|c|}{$\begin{array}{l}\mathrm{A}=\text { Overall average } \\
\mathrm{A} 1=\text { Area } 1: \text { Project manager } \\
\mathrm{A} 2=\text { Area } 2: \text { Governance } \\
\mathrm{A} 3=\text { Area } 3: \text { Client } \\
\mathrm{A} 4=\text { Area } 4: \text { Technology }\end{array}$} \\
\hline
\end{tabular}

\subsection{Updating the review framework for mining projects}

Yin [16] describes a number of analytic techniques: pattern matching, explanation building, time series analysis, logic models, and cross-case synthesis. These all represent ways of linking data to propositions. In this case, the pattern matching technique and the cross-case synthesis were the most suitable. Such a logic compares an empirically-based pattern with a single predicted pattern across the cases. If the pattern coincides, the results can help a case study to strengthen its internal validity [16].

Common themes from all four cases were compared according to the outline of the framework. The most prominent themes from each case were evaluated next to each other. By comparing the prominent themes from all four cases, the logical deduction follows that the themes that feature in two or more cases form a pattern that highlights the most prominent themes emanating from the research. This resulted in input towards an updated review framework, the salient points of which are discussed in the conclusion.

\section{CONCLUSION}

\subsection{Research results}

The results indicated that the review framework is valid, thus answering the research question positively. Although the results also indicated that some areas were not well applied in the projects (embedded cases) or in Exxaro (the holistic case), it was still deemed important and, if applied correctly, the framework application would benefit projects. Considering improvement to the framework, the following need to be addressed:

- $\quad$ Add an additional upfront EPLP phase: Due to the importance of the concept phase, a possible screening phase or FEL- 0 should be considered. During this phase the viability of a project, being part of the portfolio of projects, should be addressed.

- $\quad$ Redefine the implementation phase: Consider dividing the implementation phase into two separate phases: detail design and construction. This may assist with improved design drawings prior to beginning construction. 
- Project steering committee (Steercom): The Steercom requires a clear mandate from management when it is constituted, and should only consist of key decision-makers who can guide the project effectively and unwaveringly according to this mandate. It is essential that the Steercom closes the loop and ensures that the findings of the review are implemented.

- $\quad$ FEL guidelines: The FEL guidelines are critical components of the framework. Exxaro scored well on the core areas of geology, mining, and processing, but the research showed that other areas need improvement. A dedicated custodian should be appointed and mandated for each sub-area of the guidelines to ensure relevance and application. The guidelines applicable to a project must be confirmed at project initiation and signed off by all stakeholders.

- $\quad$ Environmental and legal: This aspect of the FEL guidelines is cause for major concern. From the interviews it became apparent that it is important to identify environmental constraints on the project as early as possible, so that sufficient time is made available to address all the statutory requirements. Many issues, such as land acquisition, cannot be left until final capital approval, and should be addressed earlier in the EPLP. The environmental and legal aspects drive the schedule of most projects, and are often on the critical path.

Considering the above observations, it is clear that the integration of all the project functions, whether geological, technical, managerial, environmental, financial, or operational. should be proactively addressed.

\subsection{Contributions to theory and practice}

There are numerous references in the literature on the theories relating to projects, EPLP, governance, and assurance. However, there is limited information on the review of project frameworks in general, and of mining projects in particular. This study describes a basic framework to follow in reviewing mining projects. The framework was validated through this research, and can be implemented by any organisation that wishes to implement a review framework for mining projects.

This research contributes to the body of knowledge about identifying project risks and quality parameters. It will also assist decision-makers to make informed decisions on key project performance parameters.

\section{RECOMMENDATIONS}

Based on the results and conclusions, the real value of this research lies in improving the project review framework. For such improvement and updating, the following are recommended:

- The framework is now validated. However, the framework can be applied to more mining related projects to develop and refine the framework further.

- $\quad$ Further research can be done to quantify the impact that the framework has on projects when it is applied.

- $\quad$ The results from the research emphasised the importance of the concept phase of the EPLP. Resources get tied up in subsequent phases of the EPLP on projects that should not have passed the first stage-gate. More work can be done on the concept study phase, to set up mining projects for success.

- Environmental and legal legislation significantly and specifically impacts the viability of mining projects. A better understanding of, and guidelines for, this aspect of mining projects can improve the projects' chances of success.

\section{REFERENCES}

[1] Rudenno, V. 2012. The mining valuation handbook. $4^{\text {th }}$ ed. Milton: John Wiley \& Sons, Inc.

[2] Pearce J.A. and Robinson R.B. 2011. Strategic management formulation, implementation and control. $12^{\text {th }}$ ed. Singapore: McGraw-Hill//rwin.

[3] Griffith, A.F. and Yarossi, M.A. 2005. Stage-gated process for project definition of capital projects. 19th IPMA World Congress. 13-16 November 2005, New Delhi. Available from: Independent Project Analysis.

[4] Merrow, E.W. 2011. Industrial megaprojects: Concepts, strategies and practices for success. Hoboken: John Wiley \& Sons, Inc.

[5] Liu, L. and Yetton, P. 2007. The contingent effects on project performance of conducting project reviews and deploying project management offices. IEEE Transactions on Engineering Management, 54(4), 789-799. 
[6] Exxaro. 2014e. Project assurance and gate reviews procedure. Pretoria: Exxaro Internal Document, PmgTemp-0020-Set1 [10].

[7] Gibson, G.E. 2013. Project definition rating index: Industrial projects. $4^{\text {th }}$ ed. Austin: Construction Industry Institute.

[8] Project Management Institute (PMI). 2013. A guide to the project management body of knowledge $\left(P M B O K^{\circledR}\right.$ Guide). $5^{\text {th }}$ ed. Newton Square: Project Management Institute.

[9] Oakes, G. 2008. Project reviews, assurance and governance. Hampshire: Gower Publishing.

[10] Bekker, M.C. 2008. Project governance for capital investments. PhD thesis. University of Pretoria.

[11] Garland, R. 2009. Project governance: A practical guide to effective project decision making. Philadelphia: Kogan Page.

[12] Murray, A. 2011. Prince $2^{\circledR}$ and Governance. UK: The Stationary Office.

[13] Noakes, M. and Lanz, T. 2012. Cost estimation handbook. $2^{\text {nd }}$ ed. Carlton: The Australasian Institute of Mining and Metallurgy.

[14] Exxaro. 2014f. Project lifecycle guidelines. Pretoria: Exxaro Internal Document, Exxdms-5271-416.

[15] Kululanga, G.K. and Kuotcha, W.S. 2008. Measuring organisational learning through project reviews. Engineering, Construction and Architectural Management, 15(6), 580-595.

[16] Yin, R.K. 2009. Case study research: Designs and methods. $4^{\text {th }}$ ed. [Kindle for iPad Version 4.4]. Thousand Oakes: Sage Publications.

[17] Mouton, J. 2001. How to succeed in your master's \& doctoral studies. Pretoria: Van Schaik Publishers.

[18] Exxaro. 2014b. Bankable feasibility study report for Mayoko project - Phase 1. Pretoria: Exxaro Internal Document, Fex-000004-Pmg-Rpt.

[19] Exxaro. 2014a. Bankable feasibility study report for Belfast project. Pretoria: Exxaro Internal Document, Cbx-000008-Pmg-Rep.

[20] Exxaro. 2014c. Bankable feasibility study report for Thabametsi project - Phase 1. Pretoria: Exxaro Internal Document, Cbx-000022-Pmg-Rep.

[21] Exxaro. 2014d. Pre-feasibility study report for Leeuwpan O/I project. Pretoria: Exxaro Internal Document, Lpx-000016-Pmg-Rep. 